\title{
POSSIBILITIES TO OBTAIN HIGHER EDUCATION IN GERMANY FOR LATVIAN BALTIC GERMAN STUDENTS (1920-1934)
}

\author{
Rudolfs Rubenis \\ University of Latvia, Latvia
}

\begin{abstract}
With the formation of the Parliamentary Republic of Latvia in the early 1920s, higher education in Latvia underwent the changes that affected the Baltic Germans. The necessity to obtain higher education in the Latvian language was perceived with mixed feelings, and the interest in the establishment and development of the University of Latvia (UL) and involvement in the reorganisation of the Riga Polytechnic Institute (RPI) went hand in hand with the reluctance to accept the full Latvianization of higher education. In the circumstances, the students used contacts established by their student corporations and sought for higher education in Germany, where it could be obtained in German but later equated to the higher education obtained in Latvia. Thus, the aim of the article is to evaluate the possibilities for the Baltic German students from the parliamentary state of Latvia (1920-1934) to study in German universities. The research is based on the documents of UL and Baltic German student corporations from the Latvian State Historical Archive (LVVA), Baltic German student corporation press (journals and anniversary books) kept in the UL Library, UL activity reports (1924-1931) stored in UL Museum history collection and available research on the Baltic German minority in the Parliamentary Republic of Latvia. The study showed that during the parliamentary period, the Latvian Baltic Germans used the state granted minority rights to find alternative ways to obtain higher education in German. The parliamentary system did not discriminate against the Baltic Germans for their use of the German language and allowed them to study in Germany but demanded that their diplomas be equated with the diploma obtained at the UL. The contacts established by student corporations helped Baltic German students to better integrate into the German study environment offering accommodation on the premises of student corporations in Germany. At the same time, additional knowledge through lectures on the political situation of Baltic Germans in the parliamentary state of Latvia did not allow them losing their historical connection with the Baltic region.
\end{abstract}

Keywords: Baltic Germans, Germany, higher education, student corporations, University of Latvia. 


\section{Introduction}

Latvian state won its independence as a result of the First World War (1914-1918) and the Latvian War of Independence (1918-1920), when the Russian, German and Austro-Hungarian empires collapsed. During those turbulent times, for the Baltic Germans the situation in higher education changed radically as Latvians had the opportunity to create their own national Alma Mater and to receive higher education in Latvian. The establishment of the University of Latvia (UL) meant Latvianization of Latvian higher education and the replacement of German and Russian language education strengthened by the Riga Polytechnical institute (RPI) from the second half of the $19^{\text {th }}$ to the beginning of the $20^{\text {th }}$ century. These changes put the Baltic Germans in an ambiguous position - they could study in German, but examinations and diploma theses had to be taken in Latvian (Bleiere et al., 2005).

The creation of Latvia and Estonia changed the Baltics, and the Baltic provinces (Estonia, Livonia and Courland) where the Russian Empire (1721-1917) had guaranteed the Baltic Germans cultural autonomy disappeared from the map. However, the Baltic Germans were able to maintain a county (Landmannaschaft) based identity by adapting to the new political order and finding ways to obtain higher education in German (Rimscha, 1968). The Baltic Germans considered Germany, with which Latvia had established contacts in the academic field, to be the land of their future possibilities. This manifested itself not only in regular business trips of UL lecturers to Germany, but also in the formation of Baltic (i. e. Latvian and Estonian) student corporation communities in the largest German cities such as Berlin, Jena, Munich, etc.

These complex changes in the history of Latvia frame the question of the research, and it is in what ways the Baltic Germans as Latvian citizens were able to obtain higher education in German if the Latvian state emphasised the strengthening of Latvianness in higher education. The study examines the significance of Baltic Germans studying in Germany for Latvian higher education taking into account the following aspects: the Baltic Germans' stance in respect of the study language in Latvian higher education, the role of student corporations in studies of the Baltic Germans in Germany, and the competitiveness of German university diplomas. Supported by a relevant document and literature review, a separate analysis of each aspect also outlines further research directions.

To understand the research question, it is necessary to explain the historiography and make a source review to explain the study of further research. Current historiography shows that Baltic Germans had interest for studies in Germany by using connections with student academical 
lifetime organisation. Raimonds Cerūzis has researched this topic, but he did not analysed competitiveness of German university diplomas to the UL diploma (Cerūzis, 2004). Nor the other historians like Leo Dribins (2004), Heinrihs Strods (1994), Andris Šnē (2009) etc. made any research in the question about Latvian Baltic German student possibilities of higher education obtain in Germany. Historians have mentioned only quotes about the Baltic German higher education obtaining question: Cerūzis and Strods mentions the language question due to latvianization of higher education; Dribins views the minority rights in Latvia as liberal excluding the fact that the language question was "frozen" and ethnic tension remained between Latvians and Baltic Germans; Šnē mentions the compromise of UL rector Augusts Tentelis but did not make any deeper research in this complicated research problem. This article is a first attempt to answer the current unanswered questions of other historians mentioned above.

The sources used in the research are from Latvian State Historical archive (1922, 1922/1923, 1930), the University of Latvia Museum and the University of Latvia Library. Unpublished Archive sources include protocols and reports of UL and Baltic German student corporations which informs about Baltic German student corporation factor on possibilities obtaining higher education in the Germany, but these sources show dry facts which were needed to synthesise with published sources like student corporation press (Grote, 1967). And monographs to create a wider picture and explanation of student corporation and other student organisation factor on obtaining higher education in Germany (Rimscha, 1968). By using the activity public reports of UL, a fact was discovered about possibilities for equitation of German university diploma with UL diploma. Sources helped also to answer questions due to previously mentioned historiography problems in Baltic German higher education research (University of Latvia, 1919-1931).

\section{Methodology}

The article is a research in history, and as such it uses historical methodology. The chronological (genetic) method is used to create a chronological description aligned to the structure of the study. After distinguishing between common and different in findings, the comparative method helps to synthesise facts discovered in protocols and reports of UL and Baltic German student organisations retrieved from the Latvian State Historical Archive, press and monographs of Baltic German student organisations kept in the UL Library, as well as previous historical research on the Baltic German minority in Latvia, and, thus, to create an analysis of the problem under research. Where the sources and literature used in the article are in Latvian and German, the translation is performed. 


\section{Baltic Germans' stance on Latvianization of higher education}

The Republic of Latvia fought for and achieved its national independence among the other new countries of Central and Eastern Europe such as Estonia, Lithuania, Poland, Czechoslovakia, Yugoslavia and Finland. In the complicated time between 1918 and 1920, the question of the future of higher education in the newly founded state of Latvia was addressed, and, after the reorganisation of the RPI, which had been founded by the Germans in 1862, the University of Latvia was proclaimed on September 28, 1919. The new Republic of Latvia was multinational, with the state nation of Latvians complemented by Russian, Jewish, Baltic German and other minorities (Dribins, 2004). The Baltic Germans faced the end of the 700 years of domination, which put them in a minority position. However, integrating the "old" RPI technical faculties with the new faculties of exact sciences and humanities in the UL structure, Latvians could not refuse to involve the Baltic Germans in the establishment of the University of Latvia (Latvian Saeima, 1923). The changes were not easy, because the Baltic Germans did not want to accept the full Latvianization of higher education at the new UL. At that time, the UL was governed by multilingualism, with the dominance of the three languages, namely, Latvian, Russian and German (Latvian State Historical archives [LVVA], 1922).

The signal of serious tension over the language issue became the walkout of all six Latvian Baltic German student corporations - founded at the University of Dorpat (Tartu) Curonia (1808) and Fraternitas Rigensis (1823), founded at the RPI Fraternitas Baltica (1865), Concordia Rigensis (1869) and Rubonia (1875), as well as founded at the UL Gotonia (1922) from the UL student corporation umbrella organisation (the Presidium Convention) on 30 October 1922. The student corporations protested against the Latvianization of the Presidium Convention meetings with the German language playing a "second-rate" role (Cerūzis, 2004). However, two years later, the situation stabilised after in June 1924, the UL Rector, Jānis Ruberts (1923-1925), reached a compromise, allowing meetings in Latvian and German, thus, facilitating the return of the Baltic German student corporations to the umbrella organization. Ruberts was a member of the Latvian student corporation Lettonia, and he was able to understand the Baltic German corporations despite the fact that his Lettonia was one of the founders of the Presidium Convention and a defender of Latvianization (Rimscha, 1968).

Although Article 3 of the UL Constitution (Satversme) approved by the Parliament of the Republic of Latvia (Saeima) on March 27, 1923, imposed Latvian as the UL official language, the de jure state was not the same as the de facto situation (Šnē, 2009). The UL Rector Augusts Tentelis (1925-1927; 
1929-1931) went much further than his predecessor Ruberts, letting lectures to be delivered in Latvian, Russian and German. However, he tried to comply with the legal obligations imposed by the Latvian state, allowing to hold entrance examinations, sessions and diploma paper defence only in Latvian (University of Latvia [UL], 1927). The UL Council was also aware that the process of Latvianization of higher education could not be implemented in a radical way, so it chose to follow the compromise policy of both UL rectors, i. e., gradual Latvianization, permitted multilingualism of lectures, but admission, sessions and graduation in Latvian only. Thus, the UL did not subject the Baltic Germans to discrimination which would prohibit any non-Latvian expression (Strods, 1994).

The Baltic Germans had a so-called "second chance" and it was to study at the Herder's Institute in Riga (Herder-Institut in Riga). There, the entrance exams, sessions and graduation process were conducted in German. The Herder's Institute in Riga was a private university where both Baltic Germans and Germans from other Central and Eastern European countries - Estonian Baltic Germans, Czechoslovak Sudeten Germans, and Romanian Transylvanian Germans - studied (Cerūzis, 2005). The private university itself was subordinated to the German Board of Education, which was under the Ministry of Education of the Republic of Latvia. The Herder's Institute in Riga did not enjoy the same rights as the UL, which reduced the prestige of the obtained diploma. The diploma was equated with the diplomas obtained at commercial institutes, which were much less prestigious than the UL diploma (Cerūzis, 2005). Despite their importance for training trade and industry specialists, commercial institutes did not have the same rights as the UL, which allowed for training specialists of a much higher level (Šilde, 1976).

As a private university, the Herder's Institute in Riga received financial support from Germany, which reached about 5 million Reichsmarks between 1923 and 1932, with the estimated amount of 625000 reichsmark per year. The Latvian government was concerned about Germany's financial support and saw it as the work of Berlin "soft power" (Cerūzis, 2005). After the First World War, Germany was one of the countries that did not accept the international order established by the Treaty of Versailles. Berlin carried out a gradual, diplomatic audit of the Versailles system. For example, in 1925, through the so-called Locarno Treaties with the Great Britain and France, German Chancellor Gustav Stresemann achieved inalterability of German western borders, thus shifting focus on Germany's eastern borders and specifically on German minorities in Central and Eastern Europe (Apals, 2020). The policy to support the rights of German minorities went hand in hand with geopolitics and help to weaken the influence of France in Poland, Czechoslovakia and other countries of their residence. Thus, 
Stresemann tried to move Germany out of its state of international oppression (Schöllgen, 2013).

\section{The role of student corporations in studies of the Baltic Germans in Germany}

Baltic German students at German universities can be divided into two groups, namely, exiles and immigrants. The Baltic German students who studied before and during the First World War at the universities of St. Petersburg and Dorpat, as well as at the RPI evacuated to Moscow in 1915, are called exiles. After the Bolsheviks seized power on November 7, 1917, the collapse of the Russian Empire was followed by the bloody Russian Civil War (1918-1921), the war forcing the Baltic Germans into exile for fear and hatred of Bolshevism. The exiles were also made up of the Baltic Germans who were deeply disappointed by the defeat of the Western Russian Voluntary Army led by Russian Colonel Pavel-Avalov Bermont in the Latvian War of Independence on November 11, 1919. The so-called Bermontiad ruined their hope to create their own Baltic state (Baltenlande). Among the disappointed were those Baltic Germans which fought for the Baltic Territorial Army (Baltische Landeswehr) and the Imperial Russian Army and were united by the hatred of Bolshevism. In their turn, immigrants are those Baltic German students who entered Germany to study in the 1920s, and their aim was to find more accessible higher education in German (Grote, 1967).

Among the Baltic German exiles and immigrants were members of student corporations who formed their own communities (corporation clusters) in Germany. For example, in 1922, Curonia established its own community in Jena, and it existed until 1934 (LVVA, 1922/1923). In 1923, Rubonia formed its own cluster in Munich, existing until 1931 (Rubonia, 1925). Student corporations are lifelong academic organisations that unite students and graduates in friendship and fraternity. They are characterised by so-called corporate seclusion manifesting itself in non-disclosure of their affairs to the public, which is similar to freemasonry. At the time, in such Organisations students had the opportunity to establish a variety of connections that would enhance their career prospects, such as studying in Germany (Cerūzis, 2004). It is important to note that to represent the interests of Baltic German students in Germany, Estonian and Latvian Baltic German students and graduates had set up their own student umbrella organisation - the Main Association of Baltic German students (Hauptverband studierender Balten (HStB)) (LVVA, 1926). This organisation had contacts with the Riga German Student Association (Deutsche Studentenschaft Riga) in Latvia and the Foreign Office of the Chargierter Convent of the University of Tartu (Chargierter Convent Dorpat), the umbrella organisation of the 
Estonian Baltic German student corporations in Estonia. Both organisations coordinated the integration of corporate Baltic German students into the German study environment (Rimscha, 1968). The corporate clusters themselves were financially maintained by senior member organisations affiliated with student corporations, which were called philistine societies. For example, on March 13, 1922, Rubonia established a branch of its philistine society in Berlin, which maintained contacts with the philistine society in Riga. The Rubonia branch of the philistine society represented the interests of its senior members in Germany, who in turn materially supported studies of their younger members in Germany (Rubonia, 1925).

Studies in Germany and belonging to one of the student corporations - Curonia or Rubonia - provided accommodation on the premises of one's corporation located in Jena, Munich or other German cities (LVVA, 1922/1923). Baltic German students also had the opportunity to gain additional knowledge by listening to their senior members' lectures on the situation of the Baltic Germans in Latvia. Among the senior members were influential personalities, such as Wilhelm von Fircks, a Member of the Saeima from the Baltic German faction (during the parliamentary period, the Baltic Germans won 6 seats), who belonged to the Baltic German People's Party. In the Parliamentary Republic of Latvia, it was a conservative political party which strongly defended the property rights of the Baltic German nobles in the difficult question of the agrarian reform. In the end of the 1920 s - the beginning of 1930s, they stood up against the dissolution of the German Education Board under the Ministry of Education and against the restrictions on the activities of Baltic German educational institutions proposed by Atis Kenins (Atis Keniñ̌̌), the Latvian Minister of Education. Kenins' policy failed due to public pressure (LVVA, 1922/1923). In Germany, Baltic German students closely followed the situation with their compatriots in Latvia, and especially the tension between Latvian state nation and the Baltic German minority. Following the political developments helped the Baltic Germans not to lose their connection with Latvia, the land where they had been born and where generations of their ancestors had been living since the times of medieval Livonia (Zeeberg, 1927).

\section{Competitiveness of the diploma obtained in German universities with the UL diploma: the case of the diploma in mechanics}

In Germany, Baltic German students mostly chose the studies in mechanics, which were prestigious at the time. The statistical data of the Main Union of Riga Baltic German Students and Tartu Chargierter Convent on the Baltic German students studying in Germany in the 1926-1927 academic year brings a total of 299 Baltic German students, with 148 Latvian, 100 Estonian and 51 German citizens respectively. It is very difficult to say how 
many Latvian, Estonian and German Baltic German students exactly studied mechanics or other disciplines. However, this does not change the fact that the most popular studies were in mechanics, with a total of 73 Baltic German students in Berlin (8), Danzig (27), Karlsruhe (21) and Munich (17). The most popular study place for Baltic Germans was Munich, with a total of 22 Baltic German students (among them 17 students of mechanics) surpassing by 8 students the number of Baltic German students of mechanics in Berlin (Chargieter Convent Dorpat und der Deutschen Studentenschaft Riga, 1927). The Baltic Germans chose to study in Munich because they were able to study mechanics at the Technical University of Munich. Moreover, with its conservative and nationalist environment Munich was politically attractive. Strongly anti-communist, Bavaria became the cradle of German monarchist and National Socialist political movements (März, 2002). Some Baltic Germans, such as the architect Alfred Rosenberg and the chemist Max von Scheubner-Richter, joined the Nazi movement. It is important to note that Rozenberg and von Richter were among the Rubonia members who formed the Munich cluster. However, not all Baltic Germans sympathised with National Socialism (Cerūzis, 2011). The UL studies in mechanics were also popular among Baltic Germans; for example, in the period between 1926 and 1931, out of the total 379 Baltic German students approximately 79 studied mechanics. There were no Baltic Germans with German citizenship studying at the UL Faculty of Mechanics in 1926-1931 (University of Latvia, 1926, 1927, 1928, 1930, 1931).

The prestige of the studies in mechanics can be explained by the fact that in the Russian Empire, the RPI served as a centre of economic growth of the Baltic provinces (Courland, Livonia and Estonia). The Baltic Germans formed the economic elite of the region and became involved in the development of industrial facilities. It was the RPI that became one of the main higher education institutions of the Russian Empire which trained technical specialists for the industrial development of the Baltic provinces and the whole country. When the UL was founded in 1919, the RPI technical faculties with Baltic German teaching staff were transferred to the university. The Baltic German technical teachers went on with the mission launched by the RPI, the strategy aimed at strengthening academic ties between the West (Germany) and the East (Russia) (University of Latvia, 1925). UL lecturers had regular foreign business trips to Germany, and it was the most frequent destination in comparison to other European countries. Based on the UL 1924-1926, 1927-1928, 1929-1930, and 1930-1931 activity reports, on average, 26 teachers went on foreign work-related trips to Germany. Out of all 773 lecturers who travelled abroad for work between 1924-1931, 110 lecturers went to Germany (University of Latvia, 1926, 1927, 1928, 1930, 1931). From the UL Faculty of Mechanics, a regular 
visitor to Germany was Professor Paul von Denffer; so, for example, in 1927, he participated in the International Mechanical Congress in Berlin (Werkstofftagung 1927) (University of Latvia, 1928), and in 1930, he visited the Fritz Werner machine and tool factory. From 5 to 31 July 1929 the professor was in Austria, where he did an internship in the metallurgical industry. In his trips, Denfers gained experience in the field of mechanics in order to improve the quality of the UL studies, thus promoting the training of specialists in mechanics for the State of Latvia (University of Latvia, 1930).

The UL lecturers in mechanics knew about the Baltic Germans studying mechanics in Germany, and they allowed the higher education diplomas obtained in Germany to be equated with the UL higher education diploma. In 1920, the UL Faculty of Mechanics emphasized that the UL could recognise the courses of mechanics obtained abroad if they were acquired at foreign universities of the same level with the UL (University of Latvia, 1925). The UL Council also worked to ensure that higher education diplomas obtained abroad were comparable with the UL higher education diplomas. Thus, according to the 1926-1927 academic year decision of the UL Council on higher education diplomas obtained abroad, there were developed and adopted regulations allowing their recognition. Thus, the Baltic German students from Latvia who acquired the education in mechanics at a German university could submit their German higher education documents for the UL review and recognition. The UL was interested in equation because it worked on deeper integration in the international scientific and study environment. (University of Latvia, 1926).

Although on February 26, 1930, the UL Council adopted regulations on the admission of members to student lifelong academic organisations, allowing only students matriculated at the UL to be admitted to these organisations, it did not prevent members of the Baltic German student corporations from studying and receiving their higher education in German universities. Having equated the diploma of higher education obtained in Germany, a member of the UL Baltic German Student Corporation was counted as a UL graduate (LVVA, 1930).

\section{Conclusion}

When the Republic of Latvia won its independence and the RPI of the former Russian Empire was taken over, the State of Latvia could neither suppress nor refuse the involvement of the Baltic Germans in the transformation of the higher education system. Whereas the knowledge and experience of the Baltic Germans was useful for the Latvian state in strengthening its academic ties with Germany, sometimes the Latvian state had to face 
the resistance of the Baltic Germans to the Latvianization of higher education. The tension in Latvian - Baltic German relations in the context of higher education remained "frozen" due to the compromises by the UL rectors.

The Baltic Germans were able to successfully use the current situation to adapt to the new circumstances in the higher education in Latvia. Through the formation of their own organisational structures in Germany, the Baltic German student corporations played an important role in establishing academic ties between Germany, Latvia and Estonia, promoting Baltic German student corporation integration into the German study environment and preserving historical ties with the Baltics (i. e. Latvia and Estonia). The documents of higher education obtained in Germany drew attention to the prestige of the acquired specialty, and it was appreciated by both Baltic Germans and Latvian state. As a state university, the UL kindly decided to recognise the equivalence of the university diplomas obtained in Germany with the UL diploma. Therefore, the integration of German and Latvian state higher education took place.

At the time of writing, there have been formulated new directions for further research of the Baltic German students in Germany. In the future, the competitiveness of the diploma in mechanics obtained by a Baltic German in Germany should be studied in comparison with the competitiveness of German diplomas obtained in other technical specialties (e. g. architecture, engineering, etc.), with the simultaneous comparison of the competitiveness of other German technical diplomas with the diploma obtained in the UL. It would also be beneficial to study deeper the inner life of the Baltic German clusters in Germany, to disclose the role of influential Baltic German personalities in Latvia and the relations of Baltic German student corporations with local German student corporations. There is also an interesting question about Germans studying in Latvia.

\section{References}

Allgemeine Statistik des Hauptverbandes studierender Balten in Deutschland für 1926/1927 [General Statistics of the Students of Baltic German student corporation in Germany for 1926/1927] (1927). Im: Chargieter Convent Dorpat und der Deutschen Studentenschaft Riga (Hrsg.). Akademisches Jahrbuch der deutsch-baltischen Studentenschaft ( $1^{\text {st }}$ Jahrgang 1927) [Academical yearbook of Baltic German student union (1 ${ }^{\text {st }}$ half 1927)] (pp. 134-135). Dorpat: Estländisches Druckerei.

Apals, G. (2020). Ārpolitikas avoti un pirmie soḷi. Latvija Versaḷas sistēmā un Otrā pasaules kara sākumā [Foreign policy sources and first steps. Latvia in the Versailles system and at the beginning of the Second World War]. In Dregger, M. (comp.). Latvijas diplomātijas gadsimts: Latvijas diplomātijas un ārlietu dienesta pirmais gadsimts (1919-2019) diplomātu esejās [The Century of Latvian Diplomacy: The First Century of Latvian Diplomacy and the Foreign Service (1919-2019) in Diplomatic Essays] (pp. 21-65). Latvia: Publishing house "Zvaigzne ABC" Ltd. 
Bleiere, D., Butulis, I., Feldmanis, I., Stranga, A., Zunda, A. (2005). Geschichte Lettlands 20. Jahrhundert [History of Latvia: the $20^{\text {th }}$ Century]. Riga: Verlag "Jumava".

Cerūzis, R. (2004). Vācu factors Latvijā (1918-1939): politiskie un starpnacionālie aspekti [The German factor in Latvia (1918-1939): political and transnational aspects.] Riga: LU Academic Publishing House.

Cerūzis, R. (2005). At the crossroads between Germany and Latvia - Herder Institute in Riga in the interwar period [Krustcēlēs starp Vāciju un Latviju - Rìgas Herdera institūts starpkaru periodā]. No: Feldmanis, I. (ed.), Zunda, A. (ed.). Starptautisko attiecïbu problēmas (Latvija, Baltija, Eiropa): profesoram Albertam Varslavānam 75 jubilejas rakstu kräjums [Problems of International Relations (Latvia, Baltics, Europe): $75^{\text {th }}$ Anniversary Collection for Professor Albert Varslavan] (pp. 63-76). Riga: LU Academic Publishing House.

Cerūzis, R. (2011). Latvijas vācu privātā augstskola: Herdera institūts (1921-1939): izglìtîba, tradīcija un ideologija [Latvian-German private university "Herder Institute (1921-1939)": education, science, tradition and ideology]. From: Bičevskis, R. (ed.). Heidegera lasijumi 1 [Heidegger Readings 1] (pp. 269-287). Riga: Institute of Philosophy and Sociology, University of Latvia. https://www.academia.edu/19265809/ The_Heideggers_Autumn_in_Riga_1928

Dribins, L. (2004). Etniskās un nacionālās minoritātes Eiropāa: vēstures un mūsdienas [Ethnic and national minorities in Europe: history and present.] Riga: Information Office of the Council of Europe.

Grote, N. von (1967). Baltische Studenten im deutschen Reich nach dem ersten Weltkrieg [Baltic students in the German Reich after the First World war]. Im: CarlSchirren-Gesselschaft e. V. Jahrbuch des baltischen Deutschtums XV / 1968 [Yearbook of Baltic Germanism XV/1968] (pp. 60-67). Hamburg: Harry v. Hofmann Verlag.

Latvijas Universitāte. Latvijas Universitātes piecgadu darbibas pārskats 1919-1924 [University of Latvia. Five-year report of the University of Latvia 1919-1924] (1925). Riga: University of Latvia edition.

Latvijas Universitāte. Latvijas Universitātes divgadu darbỉbas pārskats 1924-1926 [University of Latvia. Biennial report of the University of Latvia 1924-1926] (1926). Riga: University of Latvia edition.

Latvijas Universitāte. Latvijas Universitātes darbibas pārskats 1926-1927 [University of Latvia. Activity Report of the University of Latvia 1926-1927] (1927). Riga: University of Latvia edition.

Latvijas Universitāte. Latvijas Universitātes darbïbas pārskats 1927-1928 [University of Latvia. Activity Report of the University of Latvia 1927-1928] (1928). Riga: University of Latvia edition.

Latvijas Universitāte. Latvijas Universitātes darbïbas pārskats 1929-1930 [University of Latvia. Activity Report of the University of Latvia 1929-1930] (1930). Riga: University of Latvia edition.

Latvijas Universitāte. Latvijas Universitātes darbïbas pārskats 1930-1931 [University of Latvia. Activity Report of the University of Latvia 1930-1931] (1931). Riga: University of Latvia edition.

Latvijas Republikas Saeimas stenogrammas: I sesijas 15. sēde, 1923. gada 23. februāris [Transcripts of the Saeima of the Republic of Latvia: 15th sitting of the first session, February 23, 1923]. (1923). From: Transcripts of the Saeima of the Republic of Latvia, I session (pp. 269-305). Riga: Publication of the Saeima of the Republic of Latvia.

LVVA. 4277. f. (LU Statūti [Statutes of the University of Latvia]), Apr. 1, 331 (1922. gada LU statūti [Statutes of the University of Latvia of 1922]), p. 1. 
LVVA. 4277. f. (Rīgas Studējošo vāciešu savienība [Riga German Students' Union]), Apr. 1, 341 (Savienības statūti [Statutes of the Union]), p. 1.

LVVA. 5834 f. (LU studentu biedrība-korporācija Curonia 1920-1938 [LU Student Association-Corporation Curonia 1920-1938]), Apr. 1, 11 l (Zinojums par Curonia Jēnas kopas darbību Curonia filistru biedrībai 1922./1923. gadā [Report onof the Curonia the activities Jena Cluster to the Curonia Philistine Society in 1922/1923]), p. 15.

LVVA. 5933 f. (Biedrība "Vācu student savienība Rīgā" [Association "German Student Union in Riga"]), Apr. 1, p. 4. (Noteikumi par studentu organizācijām pie LU (apstiprināti LU Padomē 1930. gada 26. februārī) [Regulations on student organizations at the University of Latvia (approved by the Council of the University of Latvia on February 26, 1930)]), p. 1.

März, P. (2002). Freistaat Bayern [Free State of Bayern]. Im: Wehling, H.-G. (Hrsg.). Die deutschen Länder: Geschichte, Politik, Wirtschaft (2 ${ }^{\text {nd }}$ edition) [Federal states of Germany: History, Politics, Economy] (pp. 35-67). Opladen: Leske + Budrich.

Rimscha, H. von (Hrsg.) (1968). Baltisches Deutschentum: Die studentischen Korporationen der Deutschbalten, Esten und Letten einst und jetzt [Baltic Germanisms: Baltic German, Estonian and Latvian student corporations once and now]. Heidelberg: Baltischen Gesellschaft.

Rubonia: Rubonia (1875-1925): aus dem Leben eines deutschbaltischen korps [Rubonia: Rubonia (1875-1925): Life of Baltic German student corporation] (1925). Riga: Selbstverlag.

Schöllgen, G. (2013). Deutsche Außenpolitik: Von 1815 bis 1945 [German foreign policy: from 1815 till 1945]. München: Verlag CH Beck.

Strods, H. (1994). Latvijas Universitāte (1919-1940) [University of Latvia (19191940)]. From: Varslavāns, Alberts (ed.). Latvijas Universitāte 75 [University of Latvia 75] (pp. 45-71). Riga: University of Latvia.

Šilde, Ā. (1976). Latvijas vēsture (1914-1940): Valsts tapšana un suverēnā valsts [History of Latvia (1914-1940): State formation and sovereign state]. Stockholm: Daugava.

Šnē, A. (2009). Latvijas Universitātes rektors profesors Augusts Tentelis [Rector of the University of Latvia Professor Augusts Tentelis]. From: Saviča, Mārīte (comp.). Profesors Dr. honoris causa Augusts Tentelis: dzive un darbs [Professor Dr. honoris causa Augusts Tentelis: Life and Work] (pp. 7-53). Riga: LU Academic Publishing House.

Zeeberg, U. von (1927). Die baltischen Studenten in Deutschland: ihre Organisation und ihre Aufgaben [The Baltic German students in Germany: the organization and the supply]. Im: Chargieter Convent Dorpat und der Deutschen Studentenschaft Riga (Hrsg.). Akademisches Jahrbuch der deutsch-baltischen Studentenschaft (1. Jahrgang 1927) [Academical yearbook of Baltic German student union (1 ${ }^{\text {st }}$ half 1927] (41-47 pp.). Dorpat: Estländisches Druckerei. 